\title{
Brazilian bare nouns in comparatives: experimental evidence for non- contextual dependency
}

\author{
Nomes nus no Português Brasileiro em \\ comparativas: Evidência experimental \\ para não dependência contextual
}

Kayron Beviláqua * Roberta Pires de Oliveira **

\begin{abstract}
This is an empirical investigation into the volume interpretation attested for the Bare Singular (BS) in Brazilian Portuguese $(\mathrm{BrP})$ in previous studies (e.g.: Beviláqua and Pires de Oliveira (2014)). The issue is whether it is contextually dependent, as argued by Lima and Gomes (2016) and Beviláqua et al. (2016) or not. The results indicate that besides a cardinal reading, the volume interpretation is significantly associated with the BS, independently of the context. By default, the BP is compared by the number of individuals, however a volume judgment was accepted in the biased context. We conclude that the results about the BS show that its volume reading is not contextually dependent, contradicting Lima and Gomes (2016) and Beviláqua et al.'s (2016) prediction. We criticize Rothstein and Pires de Oliveira's (2016) explanation for the behavior of the BS; the authors treat it as flexible nouns in English. However, english flexible nouns in a mass context do not allow the cardinal reading. We suggest that the BS is allows for different interpretation because it denotes the kind.
\end{abstract}

Keywords: Experimental Semantics; Bare Singular; Bare Plural; Context. Count/ Mass.

UFPR 
Esta é uma investigação empírica sobre a interpretação de volume atestada para o Singular $\mathrm{Nu}(\mathrm{BS})$ no Português Brasileiro (BrP) em estudos prévios (por ex.: Beviláqua e Pires de Oliveira (2014)). A questão que se coloca é se ela é dependente do contexto, como afirmam Lima e Gomes (2016) e Beviláqua et al. (2016). Os resultados indicaram que, além da comparação cardinal, a interpretação de volume é significativamente associada ao BS, independentemente do contexto. O plural nu (BP) é normalmente comparado pro número de indivíduos apesar de ter aceitado julgamentos pro volume no contexto biased. Conclui-se que os resultados do BS mostram que sua leitura de volume não é contextualmente dependente, contrariando a predição de Lima and Gomes (2016) e de Beviláqua et al. (2016). Criticamos a explicação de Rothstein and Pires de Oliveira (2016) para o comportamento da BS; os autores o tratam como nomes flexíveis em inglês. No entanto, nomes flexíveis em inglês em contexto de massa não permitem a leitura cardinal. Sugerimos que o BS permite diferentes interpretações porque ele denota a espécie.

Palavras-chave: Semântica Experimental, Singular Nu; Plural Nu; Contexto; Contável-Massivo. 


\section{Introduction}

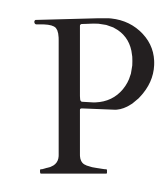

ires de Oliveira and Rothstein (2011) claim that the Bare Singular (BS) in Brazilian Portuguese $(\mathrm{BrP})$ is mass. This claim, they argue, finds support on the behavior of the BS in comparatives, since it allows for volume comparisons (1), whereas Bare Plurals (BP) only allow the cardinal comparison (2):

(1) João tem mais bola que Maria. (volume and cardinal comparisons) João havePRS.3SG more ball that Maria. ${ }^{1}$

(2)
João tem
mais bolas que Maria.
(cardinal comparison only)
João havePRS.3SG
more ball-PL that Maria.

Experimental studies have explored the behavior of the BS and the BP in comparison constructions. Beviláqua and Pires de Oliveira (2014), relying on data from a judgment task experiment, show that the BS is interpreted as mass nouns in contexts that favor a mass interpretation, though they accept a cardinal 1 In this paper we avoid the translation of the sentences to English, since there is no one to one correspondence between the two languages. 
K. BEVILÁQUA

$\&$ R. P DE

Oliveira

Brazilian

bare nouns in

comparatives:

experimental

evidence for

non-contextual dependency

comparison too. On the other hand, the presence of the plural morpheme ([-s]) only allows comparisons based on cardinality. If comparison structures are the best test for the mass and count distinction (cf. Bale and Barner (2009)), then this contrast between the $\mathrm{BS}$ and the $\mathrm{BP}$ in $\mathrm{BrP}$ shows that the $\mathrm{BS}$ behaves massively.

Beviláqua et al. (2016) and Lima and Gomes (2016) also explored the possibility of the BS being compared by volume dimensions. Beviláqua et al.'s (2016) performed a Truth-Value Judgment Test (TVJT) and the results showed that the volume comparison is unlikely to be chosen when the cardinality comparison is available for BS nous (against Beviláqua and Pires de Oliveira's (2014) results).

Lima and Gomes (2016), using quantity judgment tasks investigated BS nouns in neutral contexts (i.e. contexts that favor neither a count nor a mass interpretation). The results showed that the BS was highly compared by cardinality, i.e. speakers tend to interpret BS nouns as count nouns in neutral contexts.

These results led Beviláqua et al. (2016) and Lima and Gomes (2016) to argue that the volume interpretation of $\mathrm{BS}$ is only possible when trigged by a volume context, as exemplified below:

João tem mais livro que Maria.

(neutral context)

João havePRS.3SG more book that Maria.

(4)

João tem mais livro para pesar que Maria.
(volume context)

João havePRS.3SG more book for weigh-INF that Maria

They claim that the volume interpretation is only available for (4), since para pesar (to weigh) raises a volume reading of the noun livro (book), while in (3) there is no salient context and therefore there is no volume interpretation of the noun phrase livro. 2

In order to test Beviláqua et al. (2016) and Lima and Gomes's (2016) prediction and to arrive at a better understanding of the denotation of bare nouns in $\mathrm{BrP}$, we designed an experiment that combines the two situations tested separately in Beviláqua and Pires de Oliveira (2014) and in Lima and Gomes (2016): the behavior of the bare nouns (BS and BP) in (i) a Neutral context; and in (ii) a Biased context. By comparing the results of the volume reading in the neutral context, as in (3), and in the biased context in (4), we can evaluate whether the volume interpretation of the $\mathrm{BS}$ is only triggered by the latter. Since, we compare the BS and the BP, the experiment may also indicate whether BP nouns are sensitive to a volume context.

Revista Letras,

2 If this is the case, then there is some support to the idea that the mass reading of the BS is due to coercion. This is the main topic of Beviláqua et al. (2016).

Curitiba, UFPR, n. 96, pp.354-376,

jul./dez. 2017. ISSN 2236-0999 (versão eletrônica) 


\section{Experimental Studies on Brazilian Portuguese}

Bale and Barner (2009) claim that comparison is the best test for the mass/count distinction. If Pires de Oliveira and Rothstein (2011) are on the right track, the BS in comparison should behave massively; i.e. allowing comparison by non-cardinal scales. The following sections briefly describe the most relevant experiments the aim of which was to verify this prediction. The results support the mass view, but they differ with respect to the role of context.

\subsection{Beviláqua and Pires de Oliveira (2014)}

Beviláqua and Pires de Oliveira (2014) is the first experimental study to investigate the behavior of Brazilian bare nouns in comparatives. It is an offline experiment using the methodology of Quantity Judgment Test (QJT), proposed by Barner and Snedeker (2005). Their aim was to test two different theories for bare noun phrases in $\mathrm{BrP}$ : the count view, according to which the $\mathrm{BS}$ is a number neutral count noun (SCHMITT AND MUNN, 1999; MÜLLER, 2002); and the mass view, which treats the BS as a mass noun (PIRES DE OLIVEIRA AND ROTHSTEIN, 2011). They explored the predictions of these theories 358 by examining the behavior of native speakers when asked to perform quantity judgments. According to the count view, the BS and the BP should show the same behavior. According to the mass view, on the other hand, the BS and the BP would show different results: only the BS would allow volume interpretations ${ }^{3}$.

The test was performed by 64 participants. They were shown pictures of two persons (see below) while they listened to a short narrative, the context of interpretation. In the narrative both Joana and Maria wanted to fill the basket. Their task was to choose the best answer to the question: Quem tem mais bola para encher o cesto? (Who has more ball to fill the basket?).

3 Beviláqua and Pires de Oliveira (2014) also tested whether there was any interference of the type of noun. They compared the behavior of Count Nouns, Flexible Nouns (pedra e corda - stone and string) and the so-called Fake Mass Nouns (mobilia e bagagem - furniture and luggage). In this paper we focus on the $\mathrm{BS}$ and $\mathrm{BP}$ results. 


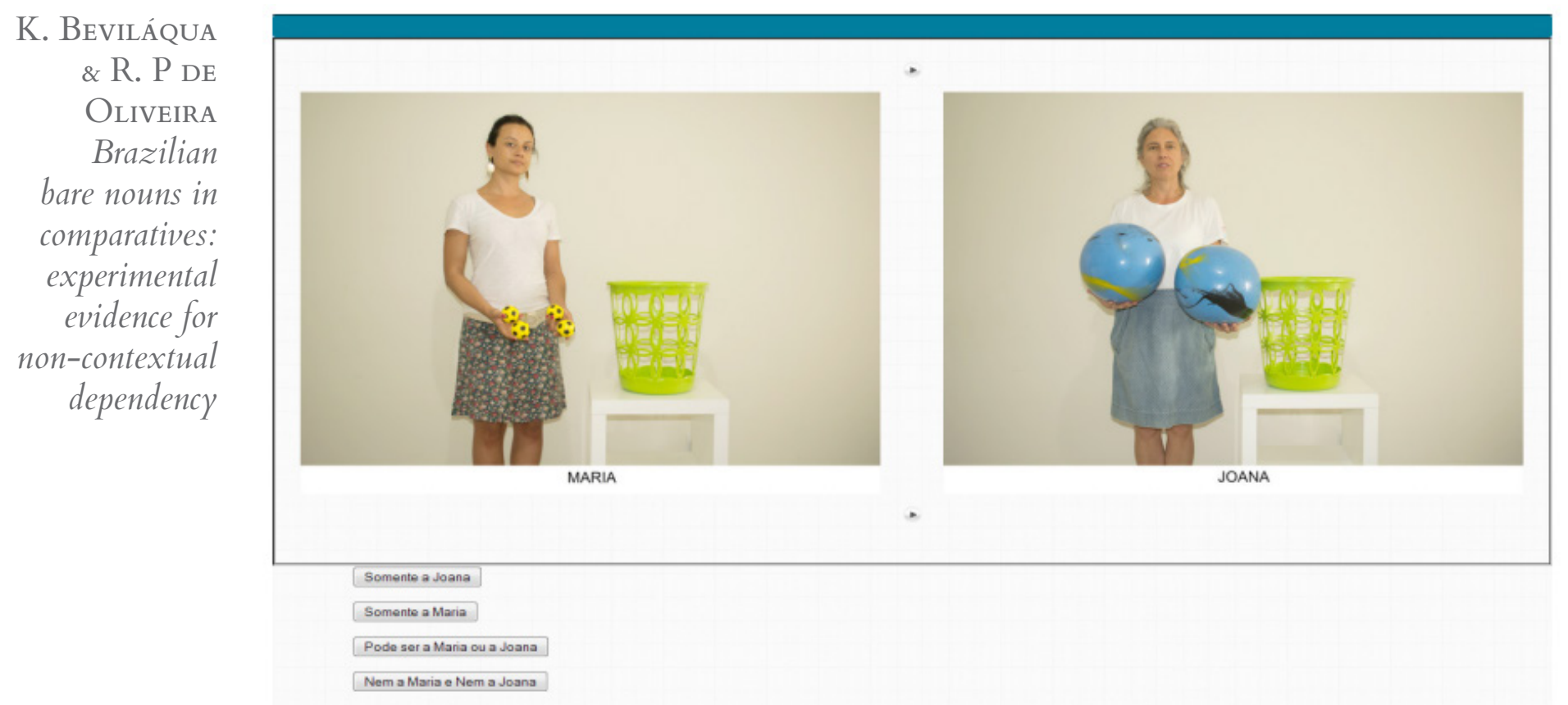

Fig.1. Sample of stimuli from the experiment of Beviláqua and Pires de Oliveira (2014, p. 263)

If the participant made the judgment based only on number, she should choose the first person. If the participants made the judgment based only on volume, they should choose the second person. It is important to notice that in this experiment the BS were tested only in a biased context, i.e. the quantity question was preceded by a context that favored volume answers. The BP nouns, in turn, were tested in a volume biased context but also in a count context. This methodology was chosen because the authors wanted to check the interpretation of the BP in volume contexts to verify whether the cardinal reading holds even in such a context.

Their results shown that, for the BS, participants based their quantity judgments on volume significantly more, despite the cardinal reading (60,94\% vs $20,31 \%)$. The results for the BP in the mass context show a different pattern: participants based their quantity judgments on the number of individuals significantly more $(72,31 \%$ vs $4,6 \%)$. BPs also allowed quantity judgments on the number of individuals significantly more $(93,75 \%)$ in the count context. Therefore, the behavior of the speakers with respect to the $\mathrm{BP}$ is not significantly different in the count and in the mass contexts.

In summary, Beviláqua and Pires de Oliveira (2014) shows that BS nouns are not equivalent to BP nouns, while BPs have a count interpretation in comparison contexts, BSs tend towards a mass interpretation.

\subsection{Lima and Gomes (2016)}

Lima and Gomes (2016) investigated whether BS nouns are better interpreted as mass nouns, or whether they may also be interpreted as object

Revista Letras,

Curitiba, UFPR, n. 96, pp.354-376,

jul./dez. 2017. ISSN 2236-0999 (versão eletrônica) 
denoting nouns. Hence, they developed an experiment to test the preferred interpretation of BS nouns in neutral contexts, i.e. contexts that favor neither a count nor a mass interpretation (differently from Beviláqua and Pires de Oliveira (2014)).

The authors performed two studies in which they compared quantities associated to characters. These two characters were always associated with the same kind of objects, but one character had a small number of objects that together had a large combined volume (Volume situation), while the other had a greater number of objects that together had a smaller combined volume (Number situation).

In Study 1, a Truth Value Judgment Test was performed by 22 participants. Besides BS nouns (e.g. carro (car)), they also tested Mass nouns (e.g. água (water)), Fake mass nouns (e.g. mobília (furniture)) and Bare plural nouns as control sentences (e.g. carros (cars)). In the Neutral Context, the sentence had the structure "A has more $x$ than B", as in Fig. 2:

\begin{tabular}{|l|l|l|l|}
\hline & List A & List B & Target question: \\
\hline $\begin{array}{l}\text { BS } \\
\text { nount }\end{array}$ & Pedro tem mais carro que \\
Júlia. \\
$\begin{array}{l}\text { Bake } \\
\text { mass } \\
\text { noun }\end{array}$
\end{tabular}

Fig.2. Sample of stimuli from the experiment of Lima and Gomes (2016, p. 203)

The results of study 1 shows that participants tended to judge BS count nouns and fake mass nouns as count nouns: $99 \%$ of number answers for BS count nouns and $97 \%$ of number answers for fake mass nouns. Bare mass nouns, on the other hand, presented only $21 \%$ of number answers.

Study 2 follows the study 1, but instead of using comparative sentences ("A has more x than B") it tested for absolute constructions, like João não tem muita bola, mas Carlos tem. ('João does not have (much/many) ball(s) but Carlos does.'). As in study 1, they tested BS nouns, Mass nouns, Fake mass nouns and Bare plurals as control sentences. The results of study 2 confirmed those of study 1. There was a high percentage of acceptance of Number descriptions with BS count nouns $(80 \%)$, fake mass nouns $(88 \%)$ and bare plural nouns $(92 \%)$. On the other hand, bare mass nouns only accepted $31 \%$ of number answers.

Both studies suggest a clear preference for BS nouns to be measured by the cardinality. Lima and Gomes suggest that this preference could be due to (i) a 
K. Beviláqua

$\&$ R. P DE

Oliveira

Brazilian

bare nouns in

comparatives:

experimental

evidence for

non-contextual

dependency

natural atomicity bias - i.e. "nouns that denote kinds whose canonical instances are individuals more likely to be grammaticalized as a count nous and to be interpreted as referring to cardinalities"; and (ii) lexical statistics - i.e. nouns that are more likely to be interpreted as a count noun due to the high frequency of their count interpretations. The authors conclude, then, that the theories of BS nouns as kind-denoting are best equipped to explain these results, since Kinds are open to different measurements.

In summary, Lima and Gomes's (2016) results suggest that "in unbiased comparative contexts, BS nouns (and fake mass nouns) have a default Cardinality/ Number interpretation, while plain mass nouns have a Volume interpretation by default". The prediction is then that mass measurement of BSs are highly unlike, unless in volume biased contexts. This paper aims at verifying this hypothesis which was also suggested by Beviláqua et al. (2016).

\subsection{Beviláqua et al. (2016)}

Beviláqua et al. (2016) developed an experiment to look more closely to the nature of the volume interpretation of BS nouns in BrP. Specifically, the authors investigated if this volume interpretation is derived from (or equivalent to) a grinding operation. Although, the hypothesis that BS nouns can be interpreted as referring to volume has received experimental support, one could argue that this volume reading is due to grinding, an operation that shifts a count predicate into a mass predicate; i.e. turning objects into the stuff they are made of. Thus, Beviláqua et al.'s (2016) main goal of was to verify experimentally if the volume reading of $\mathrm{BS}$ is (or is not) equivalent to the grinding operation.

They proposed a Truth-Value Judgment Test (TVJT) that opposed two conditions: (i) Volume and (ii) Grinding. In the volume condition, participants were presented to a video that contained one character holding an item that corresponded to theVolume answer (for ex.: a large box) while the other character had three items that corresponded to a cardinal answer (three boxes that together have a smaller volume) - See Fig.3.

In the Grinding condition, 40 participants were presented to a video of the character holding the largest item grinding it (e.g., a large box cut in several pieces); the other character had three smaller items that were not ground. They tested the BS and the BP in both contexts.

Revista Letras,

Curitiba, UFPR, n. 96, pp.354-376, jul./dez. 2017. ISSN 2236-0999 (versão eletrônica)
4 They also compared the type of noun, since the literature (Frisson and Frazier, 2005) attests that grinding is favored by food nouns. Here we will focus only on BS and BP results. 


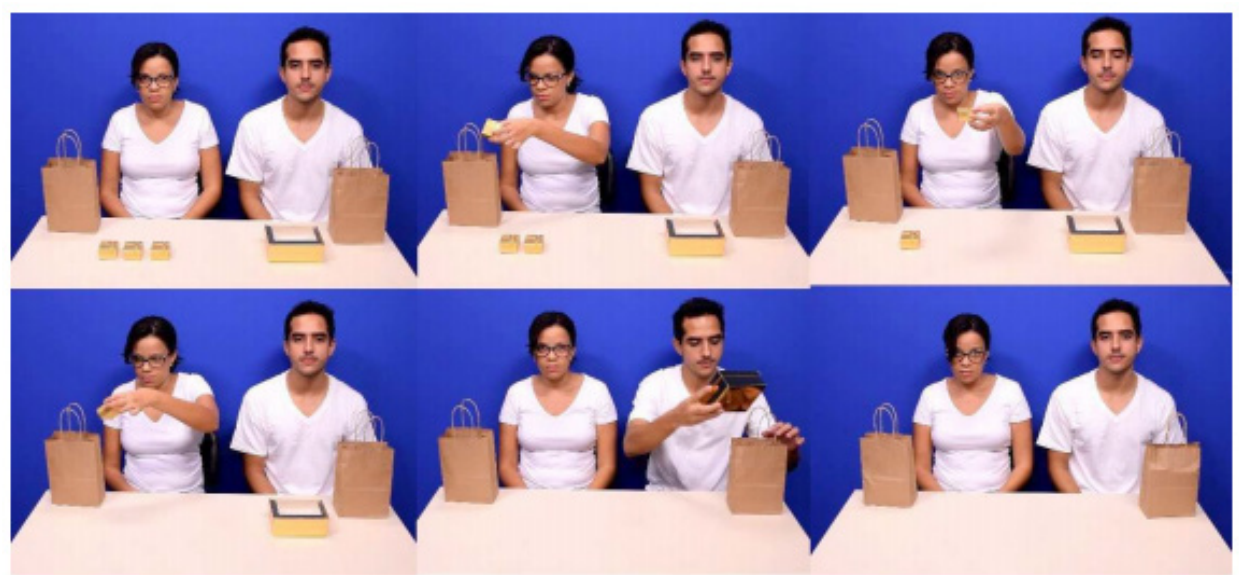

Fig.3. Sample of stimuli from the experiment of Beviláqua et al (2016, p. 10) in Volume Condition

For the BS, the results shown that, in Volume condition, participants tended to chose the cardinality answer - $65 \%$ for BS food-noun and $82 \%$ for BS object-nouns - instead of the volume answer - 35\% for BS food-noun and $17,5 \%$ for BS object-nouns. In the Grinding condition, the rate of acceptance for BS-food nouns $(62,5 \%)$ was higher in comparison with BS object nouns (15\%). Thus there was an interactions between the type of the noun and the grinding reading: BS-food nouns tend to be ground.

For BP nouns, in Volume condition, for both BP food-noun and BP object-noun, participants chose the cardinality answer (100\% and 95\%). In Grinding Condition, participants also chose the cardinality answer $(92,5 \%$ and $100 \%)$.

362 Beviláqua et al. (2016) shows that the volume dimension of comparison is unlikely to be chosen when the cardinality dimension is available for BS nouns (supporting Lima and Gomes, 2016). Moreover, BS nouns are not accepted in situations of grinding, unless the noun is a food-denoting noun. Thus, there is a lexical effect: food-denoting BS nouns are more likely to be accepted with the grinding answer in contrast to object-denoting BS nouns, which indicates that if it is possible to get volume interpretations of BS object-denoting nouns, this is not due to a ground operation.

In summary, Beviláqua et al.’s (2016) results suggest that BS have a default Cardinality/Number interpretation. Thus, we expect that mass measurement of BS nouns are highly unlike, unless in volume biased contexts. In next section we present the experiment we propose to test this assumption. 
K. BeVILÁQua

$\&$ R. P DE

Oliveira

Brazilian

bare nouns in

comparatives:

experimental

evidence for

non-contextual dependency

\section{An Experiment on Contextual Dependency ${ }^{5}$}

The experiments described in the last section differ with respect to the presence of a volume context that could lead to a comparison by volume. While Beviláqua and Pires de Oliveira (2014) only tested BS in a biased context; Beviláqua et al. (2016) and Lima and Gomes (2016) only tested BS and BP in neutral contexts. Thus, maybe their different methodologies led to different results, indicating that the volume context is crucial to a non-cardinal comparison of BS nouns.

Our experiment 6 combines, then, in the same test, the two situations: (i) the presence of a biased context and (ii) the presence of a neutral context; thus, it tests if BS nouns are compared by volume (non-cardinal) dimensions only when they appear in contexts that raise a volume comparison. The BS is compared to the BP; if the volume context is biased, then it should give rise to volume interpretations of the BP, which is normally only associated with cardinal readings.

In summary, the hypotheses to be verified are:

(i) The BS and the BP behave differently regarding quantity judgments in both contexts.

(ii) BS favors quantity judgments based on volume in both contexts.

(iii) The BP conveys a cardinal reading in both contexts.

\subsection{Methods and Design}

As previously stated, the present task explores the method of QJT developed by Barner and Snedeker (2005). We opposed two pictures containing the same kind of objects, but in one picture there is only one object that has a larger volume, while in the other picture there are three objects that together have a smaller combined volume but greater number of samples. Speakers were asked to choose the situation that is the most suitable answer for the question: Onde tem mais $X$ ? (where is there more $\mathrm{X}$ ?), where ' $\mathrm{X}$ ' was replaced by the target noun, a BS or a BP.

Since the aim is to verify whether BS and BP nouns allow volume comparison in a volume biased context, the experiment was composed by two contexts. Context 1 was composed by phrases in neutral contexts (NC), i.e, there was no information that coud raises a volume comparison. For example:

Revista Letras,

Curitiba, UFPR, n. 96, pp.354-376,

jul./dez. 2017. ISSN 2236-0999 (versão eletrônica)

5 The proposal of the current experiment was approved by the UFSC - Ethics Committee, under the number: CAAE 55936416.3.0000.0121.

6 We would like to thank Raíssa Benassi who worked with us in the experiment as an IC student. 
(5)
Onde tem
mais
garrafa?
Where havePRS.3SG more bottle-SG?

Context 2 was composed by by phrases in biased contexts (BC) and contained the exact same stimuli used in Context 1. The only difference was the presence of input that could lead to a volume interpretation, as exemplified below:

\section{(6) Onde tem mais garrafa para encher de água? \\ Where havePRS.3SG more bottle-SG for fill-INF of water-SG?}

Since the required answer was a Dimension of Comparison (Volume or Cardinality), this was our dependent variable. Therefore, the experiment was composed by two independent variables: (i) Context: NC versus BC; and (ii) Noun Type: BS versus BP. The task was presented in a computer in Google Forms. All statistical analysis were conducted in R (R Core Team, 2016).

\subsection{Materials and Procedures}

The experiment had 20 target sentences (10 for each Context) and 10 lexical items, 5 BS nouns - bola (ball), livro (book), vela (candle), garrafa (bottle) and régua (ruler) - and 5 BP nouns - bolas (balls), livros (books), velas (candles), garrafas (bottles) and réguas (rulers). All nouns have regular number inflection. The sentences were randomized and distributed in the 2 lists. If in one list there was, for instance, the item livro (book) in a singular form, the second list contained the same item, but in a plural form. Thus, the same participant did not judge the same items or the same list. 7 Fillers for each list were included to distract from the critical items.

In summary, each list was composed by 5 critical items and 7 fillers, totalizing 12 questions. Neutral Context - List 1 contained the items bola (ball), livro (book), velas (candles), garrafas (bottles) and réguas (rulers). Neutral Context - List 2 contained the inverse of the items: bolas (balls), livros (books), vela (candle), garrafa (bottle) and régua (ruler). Biased context - List 1 and List 2 was composed by the exact same stimuli used in Neutral Context, but including a biased context.

The picture below is an example of the stimuli used: 


\section{K. Beviláqua \\ $\&$ R. P DE \\ Oliveira \\ Brazilian \\ bare nouns in \\ comparatives: \\ experimental \\ evidence for \\ non-contextual \\ dependency}

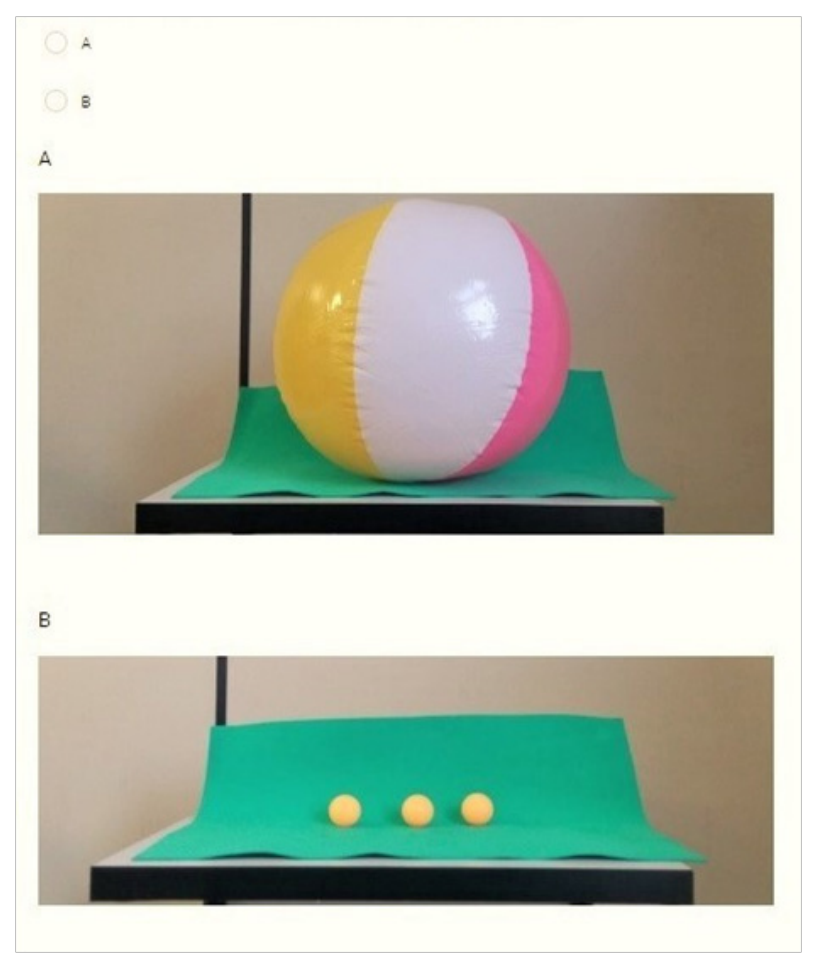

Fig.4. Sample of stimuli from the experiment

Tag questions - Context 1 (NC):

BS: Onde tem mais bola? (Where has more ball?);

BP: Onde tem mais bolas? (Where has more balls?).

Tag questions - Context 2 (BC):

BS: Onde tem mais bola para encher de ar? (Where has more ball to fill with air?);

BP: Onde tem mais bolas para encher de ar? (Where has more balls to fill with air?).

\subsection{Participants}

The sample comprises 40 undergraduate students from Universidade Federal de Santa Catarina, from different major degrees. Their participation was volunteer, and they all signed an informed consent. The data were collected in person, in the lab NEG (Núcleo de Estudos Gramaticais).
Revista Letras,

Curitiba, UFPR, n. 96 , pp.354-376, jul./dez. 2017. ISSN 2236-0999 (versão eletrônica) 


\subsection{Results and Statistical Analysis}

In this section we present the descriptive results (bar graphs with lengths proportional to the values that they represent) and the statistical analysis. We performed a linear mixed-effects regression analysis, since each participant gave multiple responses (following Winter (2013) and Gries (2013)). Mixed-effects regression models allows to deal with random effects (i.e. variables the effect of which should not interfere in the measures, but we know it may be there). Mixed models take into account both (1) the variation that is explained by the independent variables of interest - called fixed effects - and (2) variation that is not explained by the independent variables of interest - called random effects (WINTER (2013)). All statistical analysis were conducted in R (R CORE TEAM, 2016) using the package lme4 (BATES et al. 2016).

The null hypothesis is that there is no correlation between the independent variables - 'Context' (Neutral vs. Biased) and 'Noun Type' (BS vs. BP) - affecting our dependent variable ('Quantity judgments': Volume vs. Cardinality), while also taking into account the random intercepts for each participant and lexical item (letting the intercept vary by participant and lexical item). Our formula, then, can be expressed as:

(7) $\quad$ glmerMod (Answer $\sim$ Context ${ }^{\star}$ Noun.Type $+(1 \mid$ Participant $)+(1 \mid$ Item $\left.)\right)$

The output of the statistical test is presented below:

\begin{tabular}{|c|c|c|c|c|}
\hline \multicolumn{5}{|l|}{ Fixed effects: } \\
\hline & $\begin{array}{l}\text { Es t i m a te } \\
\text { Std. }\end{array}$ & Error & $z$ value & $\operatorname{Pr}(>|z|)$ \\
\hline (Intercept) & -4.263 & 1.118 & -3.813 & $0.000137^{\star \star \star}$ \\
\hline Context 2 & 3.338 & 1.249 & 2.672 & $0.007542^{\star \star}$ \\
\hline Noun. TypeS & 5.474 & 1.364 & 4.014 & $5.98 \mathrm{e}-05^{\star \star \star}$ \\
\hline Context2:Noun.TypeS & -3.061 & 1.450 & -2.112 & $0.034726^{\star}$ \\
\hline \multicolumn{5}{|c|}{ 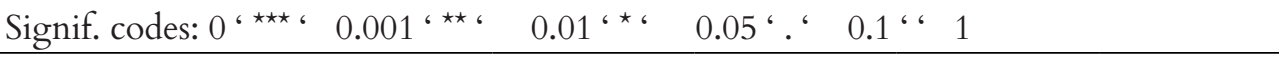 } \\
\hline
\end{tabular}

Table 1: Output of Generalized linear mixed model fit by maximum likelihood test

The $\mathrm{p}$-values (represented in the table by "Pr") show that all of the effects are significant at a significance level of $5 \%$, which means that there is a significant interaction in the model, demonstrating that the answer (volume or number) changes 
K. Beviláqua $\&$ R. P DE Oliveira Brazilian bare nouns in comparatives: experimental evidence for non-contextual dependency

depending on the combination between the Noun Type and the Context. The null hypothesis is then rejected.

\subsubsection{Correlation between Contexts (NC vs. BC)}

The results for BS in both contexts are presented in the following graphic:

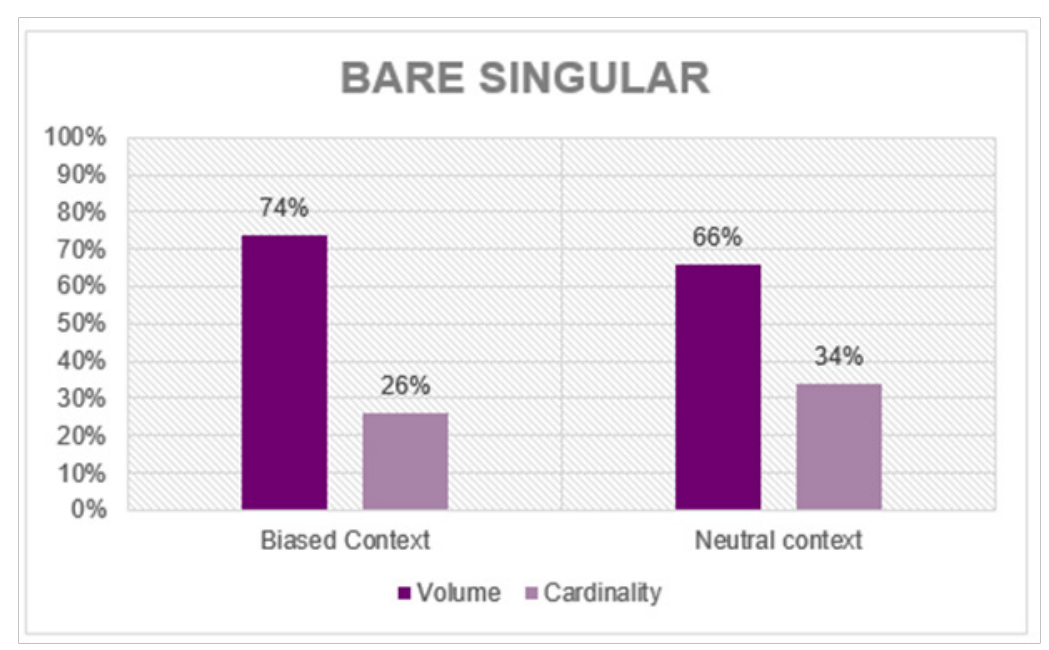

\section{Graph.1. Quantity judgments for BS in neutral and biased contexts}

The volume answer was preferably chosen for the BS both in the biased context and in the neutral context. The cardinal answer was also accepted, although in a numerical disadvantage.

The results for the BP in both contexts (biased and neutral) are presented in the next graphic:

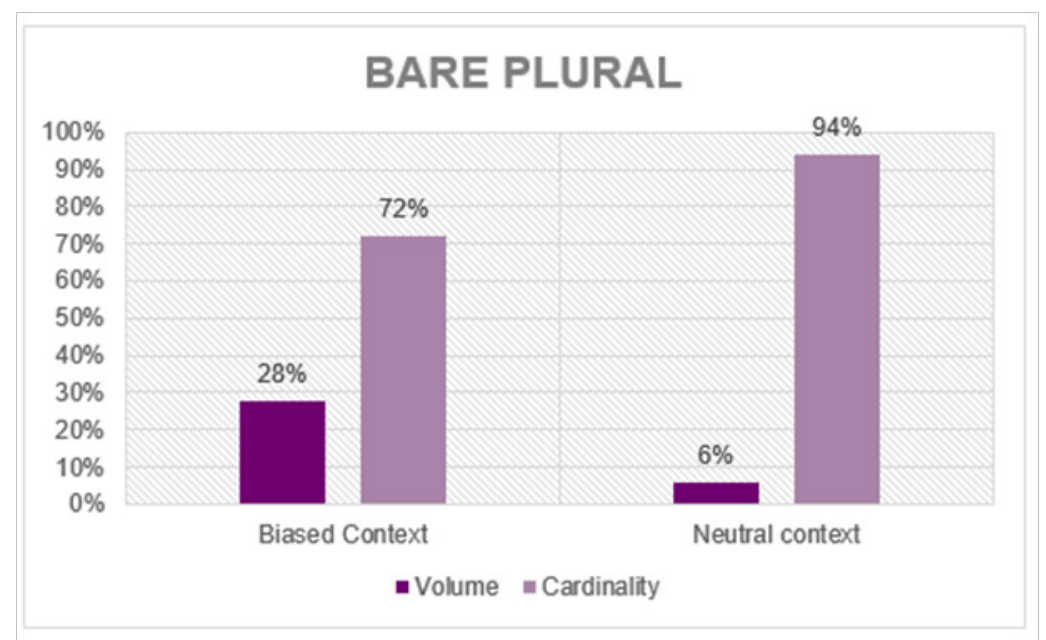

Graph.2. Quantity judgments for BP in neutral and biased contexts

In contrast, for the BP, the cardinal answer was highly chosen in both contexts. As expected, there is a considerable number of volume answers, in a rate of $28 \%$, for the biased context.

Revista Letras, Curitiba, UFPR, n. 96 , pp.354-376, jul./dez. 2017. ISSN 2236-0999 (versão eletrônica) 
In order to see whether the difference between the biased and the neutral contexts is significative with respect to the noun type, we run the statistical test. In other words we wanted to verify if, regarding the variable 'NounType' individually, there is a difference between $\mathrm{NC}$ and $\mathrm{BC}$ :

\begin{tabular}{|l|l|l|l|l|l|l|l|}
\hline$\# \#$ & contrast & NounType & odds.ratio & SE & df & asymp.LCL & asymp.UCL \\
\hline$\# \# 1$ & NC - BC & BP & 0.05196397 & 0.05124234 & NA & 0.007521795 & 0.3589907 \\
\hline$\# \# 2$ & NC - BC & BS & 0.81099292 & 0.56799558 & NA & 0.205523051 & 3.2001739 \\
\hline
\end{tabular}

Table 3: Output of Odds ratio for Context considering the variable NounType individually

Interpreting the results above, we can affirm that, considering the BP noun type, there is a significative difference between NC and BC ( $p=0.007521795)$. On the other hand, considering the BS noun type, there is no significative difference between NC and $\mathrm{BC}(\mathrm{p}=0.205523051)$. In terms of odds ratio, the chances for the answer 'Volume' in the Biased Context is 19.2441 more than in the $\mathrm{NC}$ regarding the $\mathrm{BP}$; and 1.233056 more than the $\mathrm{NC}$ regarding the $\mathrm{BS}$.

As predicted by our hypothesis (ii) the BS favored quantity judgments based on volume in both contexts, which indicates that the volume interpretation of the BS is not contextually dependent. On the contrary, against our hypothesis (iii), the BP did not favored only quantity judgments based on number in the Biased Context. In the $\mathrm{BC}$ there was a slight greater acceptance of volume answers (28\%). We discuss this result in the next section.

\subsubsection{Correlation between the Noun Type (BS vs. BP)}

Now, we present the results for both the BS and the BP in the neutral context:

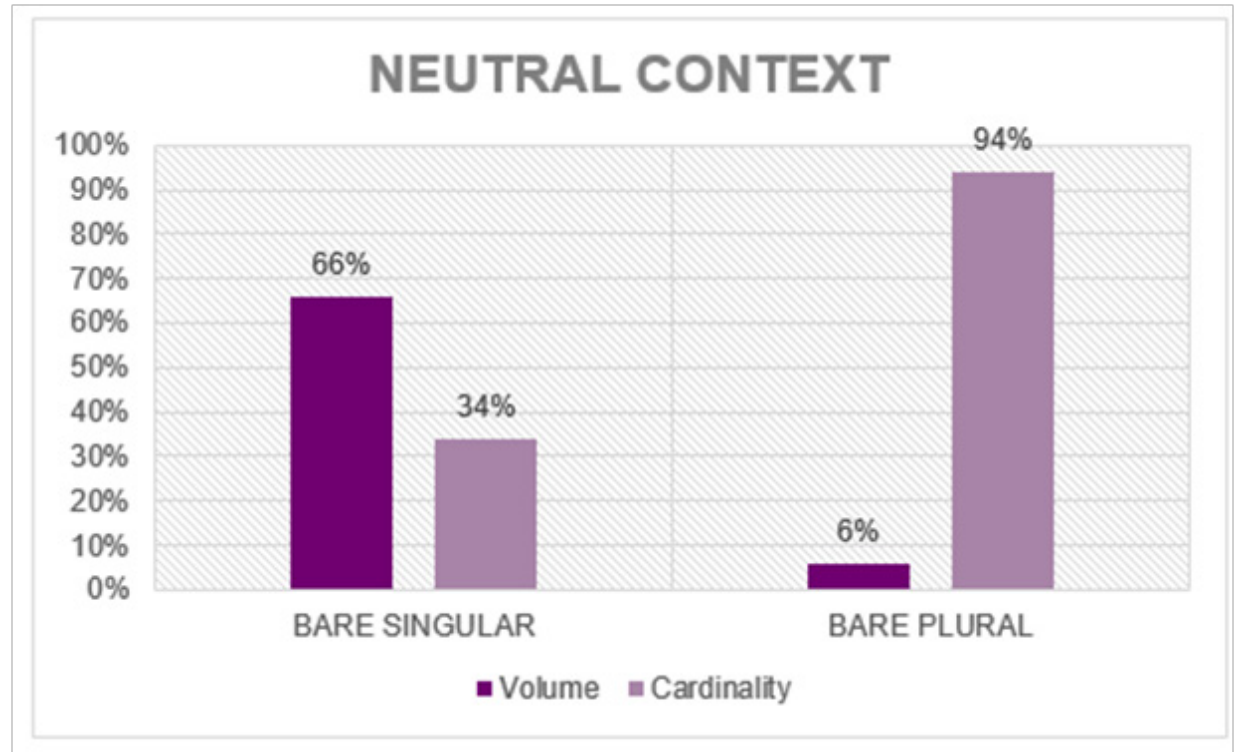

Graph.3. Quantity judgments for BS and BP in a neutral context 


\section{K. Beviláqua}

$\&$ R. P DE

Oliveira

Brazilian

bare nouns in comparatives:

experimental evidence for non-contextual dependency
There is a clear a difference between the $\mathrm{BS}$ and the $\mathrm{BP}$ regarding both volume and cardinal answers in the neutral context: the BS allows preferentially volume quantity judgments (66\%) opposed to the BP (6\%).

Similarly, we present the results for both BS and BP in the biased context:

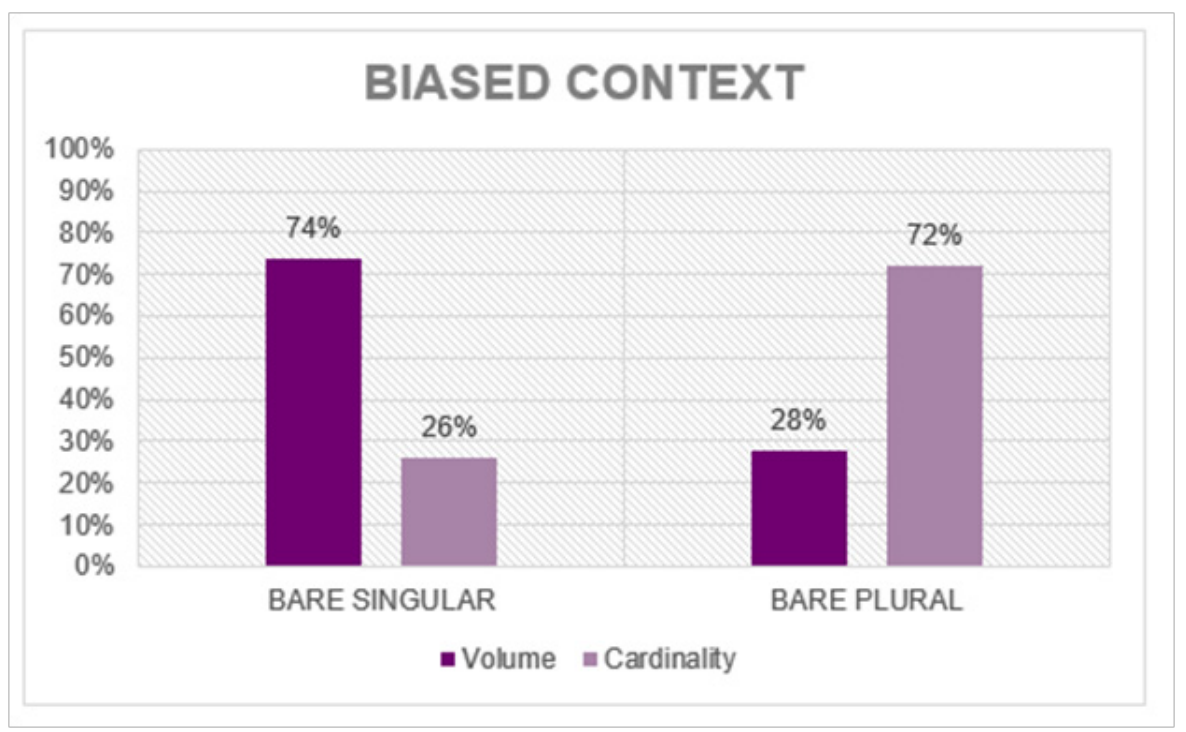

\section{Graph.4. Quantity judgments for BS and BP in a biased context}

Analogously to the results of neutral context, there is a difference between the BS and the BP regarding both volume and cardinal answers in the biased context. The BS allows preferentially volume quantity judgments (74\%), whereas the BP has an acceptance of $28 \%$.

In order to verify whether the difference between the BP and BS is significative with respect to the context, we run the statistical test. We wanted to verify if, regarding the variable 'Context' individually, there is a difference between the BS and the BP:

\begin{tabular}{|l|l|l|l|l|l|l|l|}
\hline$\# \#$ & contrast & Context & odds.ratio & SE & df & asymp.LCL & asymp.UCL \\
\hline$\# \# 1$ & BP - BS & NC & 0.007980911 & 0.008364675 & NA & 0.001023106 & 0.06225643 \\
\hline$\# \# 2$ & BP - BS & BC & 0.124556730 & 0.065461258 & NA & 0.044464665 & 0.34891478 \\
\hline
\end{tabular}

\section{Table 2: Output of Odds ratio for NounType considering the variable Context individually}

Interpreting the result of the table above, we can affirm that, considering only the Neutral context, there is a significative difference between BP and BS $(p=0.001023106)$. Moreover, considering only the Biased context, there is also a significative difference between BP and BS ( $p=0.044464665)$. In terms of odds ratio, the chances of the $\mathrm{BS}$ accept the answer 'Volume' is 125.299 more than the $\mathrm{BP}$ in the NC; and the chances of the BS accept the answer 'Volume' is 8.02847 more than the $\mathrm{BP}$ in the $\mathrm{BC}$.

Revista Letras,

Curitiba, UFPR, n. 96, pp.354-376, jul./dez. 2017. ISSN 2236-0999 (versão eletrônica) 
As predicted by our hypothesis (i) and in line with the previous experiment discussed in section 2, the BS and the BP differ regarding quantity judgments. The results show that BSs allow quantity judgments based mostly on volume - in both contexts - while BP allows quantity judgments based mostly on cardinality - in both contexts.

\section{General Discussion}

The results of our experiment allow three conclusions:

(i) the Bare Singular and the Bare Plural do not behave in the same way in both the neutral and the biased contexts (see Graphs 3 and 4). These results are in line with Beviláqua and Pires de Oliveira's results and, as discussed by them, they do not give support to the number neutral view (Schmitt and Munn (1999) and Müller (2002)), according to which the BS and the BP should have the same behavior, since they are plural count nouns.

Next, (ii) there is no significant difference in the use of the BS in the neutral and in the biased context (see Graph. 1). If the volume reading of the Bare Singular were contextually dependent, the prediction was a significant increase of volume interpretation in the biased context. However, this is not what the results show. On the contrary, there is no significant difference between the neutral and the biased contexts. This strongly suggests that the volume interpretation of the BS is not dependent on the context (against Lima and Gomes (2016) and Beviláqua et al (2016)).

Finally, (iii) our results show that there is a significant difference in the use of the BP in the neutral and in the biased context (see Graph. 2). Although the $\mathrm{BP}$ is compared by cardinality in both contexts, in the $\mathrm{BC}$, there is a significant increase of volume interpretation due, naturally, to the input that raises volume interpretation. Participants were sensitive to the contextual clue and coerced the count predicate into mass. This results shows that the context was biased by volume. $^{7}$

Moreover, there is an issue that we need to discuss about conclusion (i) and the denotation of the BS. BSs allow preferentially quantity judgments based on volume in both contexts, but it also allows a cardinality judgment. As shown in Graph 1, 26\% of the answers for the BS were comparisons by number in the $\mathrm{BC}$; and $34 \%$ in the NC. This is a relevant rate. Thus, it seems that the BS allows both for cardinal and non-cardinal interpretation, against Bale and Barner's (2009) generalizations: if the noun were count, no mass interpretation

$7 \quad$ This could lead us to think that the volume BS results in the biased context was also due to a contextual force and coercion. However, this is not the case. If the BS were contextually dependent the prediction was a significant increase of volume interpretation in this context. However, this is not what the results show. There is no significant difference in the use of the Bare Singular in the neutral and in the biased context. 
K. BEVILÁQUA

$\&$ R. P DE

Oliveira

Brazilian

bare nouns in

comparatives:

experimental

evidence for

non-contextual dependency

is expected; if it were mass, no cardinal interpretation is expected. Pires de Oliveira and Rothstein's (2011) account for BSs explains their volume quantity judgments. However we need to offer an explanation that tells apart BSs from substance mass bare nouns, because it seems clear that substance mass bare nouns, like água (water), at least in BrP, do not behave like BS nouns since they do not accept number quantity judgments. Nonetheless, our results show that the BS is also interpreted by cardinalities.

Although it is not the aim of this paper to compare the two different theories for BS in BrP - the number neutral view (SCHMITT; MUNN, 1999; MÜLLER, 2002, among others); and the mass view (PIRES DE OLIVEIRA; ROTHSTEIN, 2011) - since this was already made by Beviláqua and Pires de Oliveira (2014), it is important to state that according to the number neutral approach BSs are open to be interpreted as atomic individual or as a set of sums of individuals without the atoms, but not as mass. This approach, then, leaves without explanation the results found in our experiment.

Moreover, Müller (2000; 2002) and Müller and Oliveira (2004) argue that the $\mathrm{BS}$ in $\mathrm{BrP}$ do not denote the kind, because, according to these authors, it does not combine with kind predicates ${ }^{8}$, but they are silent about the possibility of BSs being mass measured. In this paper our aim is to explain the mass reading which seems to be attached to the BS.

Rothstein and Pires de Oliveira's (2016) explanation for the behavior of the BS in comparison is double: they distinguish, relying on Rothstein (2017), counting and measuring. Counting is an operation of pairing individuals and cardinals which requires semantic atoms, whereas measure is projecting an individual into a point in a scale. Thus, the cardinal reading of atomic mass nouns such as furniture in English, attested by Barner and Snedeker (2005) among others, is not counting but measuring using a cardinal scale. Its noncardinal interpretation, attested in Grimm and Levin (2012), is explained by the use of a different scale. The authors argue that the cardinal reading of the BS in $\mathrm{BrP}$ is measuring, whereas the cardinal interpretation of the $\mathrm{BP}$ is achieved via counting, which is possible because the $\mathrm{BP}$ has semantic atoms in its denotation. The BS is mass, so its denotation has no atoms accessible to the grammar, though it may have natural atoms.

A consequence of such a proposal is that all count nouns in $\mathrm{BrP}$ are ambiguous between mass and count. Thus, they argue that "count" nouns in BrP are a Flexible nouns. They rely on Bale and Barner's (2009) nominal classification which distinguishes: count nouns (books), substance nouns (water), atomic mass nouns (furniture), and flexible nouns (rope). In Bale and Barner's proposal, flexible nouns refer to a small set of nouns in English which are sometimes interpreted as a mass noun or a count noun (e.g. stone and paper). In comparatives, flexible nouns in English are interpreted as mass nouns when they appear in a mass syntax, i.e. in a "singular" form (e.g. This garden has more stone than that); 8 See Wall (2015) for data collected examples of BSs with kind predicates.

Revista Letras,

Curitiba, UFPR, n. 96, pp.354-376,

jul./dez. 2017. ISSN 2236-0999 (versão eletrônica) 
and they behave as count nouns when they appear in a count syntax, i.e. when they are pluralized (e.g. John has more stones than Mary). Rothstein and Pires de Oliveira (2016) suggest that there is a pragmatic constraint that blocks the cardinal interpretation of the Bare Singular in English. Since in English all nouns are either mass or count, the Bare Singular is interpreted as mass. If the speaker intends a cardinal interpretation he should use the count counterpart, i.e. the plural form; since he has used the Bare Singular is because he intends a mass interpretation.

It is not our aim in this paper to discuss this proposal in depth, but to point to some difficulties and to suggest a different explanation. First, flexible nouns in English are very restricted, whereas there seems to be no restriction with the $\mathrm{BS}$ in $\mathrm{BrP}$. Their proposal leads to assume that all nouns in the lexicon in $\mathrm{BrP}$ are ambiguous between count and mass. Every count noun is a singular atomic predicate and a mass predicate. This seems paradoxical. Second, in English a count predicate in a mass syntax must be interpreted massively as is the case of:

(8) There is apple in the salad.

Coercion of count to mass is due to the presence of an atomic predicate in a mass context. In BrP, the translation of (8) is under-specified as it happens with any other noun in this language:

(9) Tinha maçã na salada.

372 (9) may be interpreted as referring to apples as well as to apple stuff. The behavior of Bare Singulars in these two languages is not the same, contrary to their prediction.

Third, their approach predicts that in the right context the BS in English may be interpreted by cardinality. This needs to be checked but our informal survey casts doubts on it. We have asked 3 native speakers about the interpretation of John has more stone than Mary to fill the holes in a board, in a context where John has 3 small stones and Mary has one stone the volume of which is greater than the volume of the three stones. They unanimously refused the sentence, though the context was biased for cardinality.

A different solution is to distinguish kind from mass denotation. One of the consequences of Chierchia's (1998) famous semantic parameter was the conflation of kind and mass denotations. The 'up' operator applied to kinds generated mass denotations. In Mandarin all bare nouns denote the kind because nouns were mass, the author argued. However in his more recent papers, Chierchia (2014), kinds are distinguished from mass. In Mandarin, for instance, bare nouns denote the kind but are not necessarily mass. Otherwise, it is difficult to explain why certain classifiers only combine with count nouns, 
K. BEVILÁQUA

$\&$ R. P DE

Oliveira

Brazilian

bare nouns in

comparatives:

experimental

evidence for

non-contextual dependency

as shown by Cheng and Sybesma (1998). Suppose this is so. Suppose, moreover, that in the spirit of Carlson's proposal (1977) kinds denote realizations, and not lattice structures which is the denotation of plural predicates. What counts as a realization of the kind is contextually dependent. Thus, it may be one individual or several individuals. Since it does not denote a lattice structure, one may consider groups of individual, without considering the atoms. This allows for non-cardinal interpretations. One may also consider the atomic individuals, and then we have a cardinal reading. Thus, we arrive at both readings without the need to distinguish between counting and measuring.

In the context of comparisons one may be comparing the number of instantiations of the kind or one may be grouping the individuals and comparing the amount of them. If it is clear in the context that one is talking about just one particular individual, then, given that comparison structures require 'Monotonicity' (see SCHWARZCHILD (2002)), the interpretation is massive. This is the only possibility for English because in English the Bare Singular is a singular predicate, i.e. atomic. This explains the contrast between these two languages in the examples below:

(10) a. There was cat all over the place.

$$
\text { (smashed cat) }
$$

b. Tinha gato pra tudo quanto é lugar.

(cardinal, volume or smashed cat)

In English, cat denotes an atomic predicate, as apple in (8) or stone in (11). Since they are atomic predicates in mass syntax they are coerced to mass. This is the only alternative for English.

There are more stone here than there.

In $\mathrm{BrP}$ the $\mathrm{BS}$ denotes the kind and in the context of comparison is shifted to its realization. Since realizations are not closed under sum, any interpretation is allowed. In this view, nouns in $\mathrm{BrP}$ are either mass or count. Count nouns can be combined with numerals as in 3 gato $\left(3\right.$ cat), mass nouns cannot, ${ }^{\star} 3$ mobilia ( 3 furniture). But the BS denotes the kind; in comparison the individual is shift to its realizations, which may range from atoms to any grouping of individuals. A cardinal comparison relies on atomic realizations; the volume reading is due to grouping the individuals by volume. The volume reading is not allowed for the BP because it is a sum structure. In our experiment, the tendency to volume reading may well be due to the contrast with the BP. Since only the BS allows for a non-cardinal interpretation, and in the context of the task it was implicitly compared to the Bare Plural, the volume interpretation was prominent even in

Revista Letras,

Curitiba, UFPR, n. 96, pp.354-376,

jul./dez. 2017. ISSN 2236-0999 (versão eletrônica) 
neutral contexts. In Lima and Gomes (2016), the context makes the number of individuals salient, and that may explain the results.

\section{Conclusions}

This paper presents the results of an offline quantity judgment task which compares the behavior of the BS and the BP in neutral and biased contexts. The aim was to investigate whether the attested volume reading of the BS is contextually dependent. The results show that this is not the case: the BS was interpreted as volume in both context, whereas the BP was interpreted as volume only in the biased context. But the BS accepts cardinal readings as well. It seems then to be under-specified. We suggested that this under-specification may be explained by its denotation: the BS denotes the kind which is shift to realizations; the $\mathrm{BP}$ denotes a plural predicate which is interpreted by the number of individuals except if the context coerces it into mass, as in our biased context. 
K. Beviláqua

\& R. P DE

Oliveira

Brazilian

bare nouns in

comparatives:

experimental

evidence for

non-contextual

dependency

\section{References}

BALE, ALAN; BARNER, DAVID. The interpretation of functional heads: Using comparatives to explore the mass/count distinction. Journal of Semantics v. 26, n. 3, p. 217-252. 2009.

BARNER, DAVID; SNEDEKER, JESSE. Quantity judgments and individuation: evidence that mass nouns count. Cognition, n. 97, p. 41-66. 2005.

BATES, D.; MAECHLER, M.; BOLKER, B.; WALKER, S. _lme4: Linear mixed-effects models using Eigen and S4_. R package version 1.1 -7. Disponível em http://CRAN.R-project.org/package=lme4. Acesso em 2016.

BEVILÁQUA, KAYRON; LIMA, SUZI; PIRES DE OLIVEIRA, ROBERTA. Bare Nouns in Brazilian Portuguese: An experimental study on grinding. The Baltic International Yearbook of Cognition, Logic and Communication. Vol. 11: Number: Cognitive, Semantic and Crosslinguistic Approaches. 2016.

BEVILÁQUA, KAYRON; PIRES DE OLIVEIRA, ROBERTA. Brazilian bare phrases and referentiality: evidences from an experiment. Revista Letras, Curitiba, n. 90, p. 253-275, jul./dez. 2014.

CARLSON, GREGORY. Reference to Kinds in English. UMass Ph.D. diss. Published 1980, New York: Garland Press. 1977.

CHENG, LISA; SYBESMA, R. Yi-wan tang, yi-ge tang: Classifiers and massifiers. The Tsing Hua Journal of Chinese Studies, New Series. 1998.

CHIERCHIA, GENNARO. How universal is the mass/count distinction? Three grammars of counting. In: LI, Audrey; SIMPSON, Andrew; TSAI, WeiTien Dylan (Eds.). Chinese Syntax in a Cross-Linguistic Perspective. Oxford Scholarship Online: November. 2014.

Reference to kinds across languages. Natural Language Semantics, v. 6, n. 4, p.339-405. 1998.

FRISSON, STEVEN; FRAZIER, LYN. Carving up word meaning: Portioning and grinding. Journal of Memory and Language, n. 53, p. 277-91. 2005.

GRIES, STEPHAN. Statistics for Linguistics with R: a practical introduction. Berlin, Boston: de Gruyter Mouton. 2013.

GRIMM. Scott; LEVIN. Beth. Who has More Furniture? An Exploration of the Bases for Comparison. In: MASS/COUNT IN LINGUISTICS, PHILOSOPHY AND COGNITIVE SCIENCE CONFERENCE, dez. 2012, École Normale Supérieure, Paris, France. Disponível em: <http://migre.me/n6qLu>. Acesso em: 25 nov. 2016.
Revista Letras,

Curitiba, UFPR, n. 96 , pp.354-376,

jul./dez. 2017. ISSN 2236-0999 (versão eletrônica) 
LIMA, SUZI; GOMES, ANA PAULA QUADROS. The interpretation of Brazilian Portuguese bare singulars in neutral contexts. Revista Letras, Curitiba, n. 93 p. 193-209, Jan./Jun. 2016.

MÜLLER, ANA. Sentenças genericamente quantificadas e expressões de referência a espécies no português do brasil. Cadernos de Estudos Linguísticos (UNICAMP), Campinas, v. 39, p. 141-158, 2000.

- The Semantics of Generic Quantification in Brazilian Portuguese. Probus v. 14, p. 279-298. 2002.

MÜLLER, ANA; OLIVEIRA, FATIMA. Bare Nominals and Number in Brazilian and European Portuguese. Journal of Portuguese Linguistics, Portugal, v. 3, n.1, p. 9-36, 2004.

PIRES DE OLIVEIRA, ROBERTA; ROTHSTEIN, SUSAN. Bare Singular noun phrases are mass in Brazilian Portuguese. Lingua, n. 121, 2011.

R CORE TEAM. R: A language and environment for statistical computing. R Foundation for Statistical Computing, Vienna, Austria. URL http://www.Rproject.org/. 2016.

ROTHSTEIN, SUSAN. Semantics for Counting and Measuring. Cambridge University Press. 2017.

ROTHSTEIN, SUSAN. PIRES DE OLIVEIRA, Roberta. Comparatives in Brazilian Portuguese: Counting and measuring. In: MOLTMANN, F. (Ed.). Mass and Count in Linguistics Philosophy, and Cognitive Science. John 376 Benjamins: Amsterdam. 2016.

SCHMITT, CRISTINA.; MUNN, Alan. Against the nominal mapping parameter: Bare nouns in Brazilian Portuguese. Proceedings NELS, n. 29, p. 339-353. 1999.

SCHWARZSCHILD, ROGER. The grammar of measurement. In:JACKSON, Brendan (Ed.). Proceedings of SALT XII, Ithaca, NY: CLC Publications. 2002.

WALL, ALBERT. Bare Nominals in Brazilian Portuguese, an integral approach. PhD Dissertation, University of Zurich. 2015.

WINTER, BODO. Linear models and linear mixed effects models in R with linguistic applications. 2013. Disponível em: <http://arxiv.org/pdf/1308.5499. pdf $>$. Acesso em 20 de dez. 2016.

Submetido em: 05/03/2017

Aceito em: 06/06/2017 